\title{
Border crossings in the African travel narratives of Ibn Battuta, Richard Burton and Paul Theroux
}

\author{
F. Fiona Moolla* \\ University of the Western Cape, South Africa
}

This article compares the representation of African borders in the 14th century travelogue of Ibn Battuta, the 19th--century travel narrative of Richard

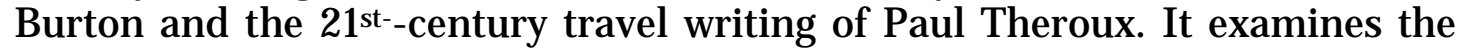
mutually constitutive relationship between conceptions of literal territorial boundaries and the figurative boundaries of the subject that ventures across borders in Africa. The border is seen as a liminal zone which paradoxically separates and joins spaces. Accounts of border crossings in travel writing from different periods suggest the historicity and cultural specificity of conceptions of geographical borders, and the way they index the "boundaries" of the subjects who cross them. Tracing the transformations in these conceptions of literal and metaphorical borders allows one to chart the emergence of the dominant contemporary idea of "Africa" as the inscrutable, savage continent.

Key words: travel narrative; Africa; border crossings; autobiography; rites of passage; the self

Travel seems to be as ancient as the origins of human society itself. Throughout various oral and textual traditions, travel, in the form of journeys, emigrations, exiles and diasporic movements, appears to be a constitutive element of the mythologies of most religions. The centrality of the journey in the Hindu Mahabharata, in Buddha's wanderings, and in the idea of exile in the founding narratives of the Abrahamic faiths has been noted by Tabish Khair in Other Routes: 1500 Years of African and Asian Travel Writing (1). Travel is a significant trope in the mythologies of most African cultures. For example, among the Yoruba, Ogun, the god of iron and of the road, forges the path which reconnects the deities with human beings. Voyages are almost always a structural element of the epic myths associated with the founding of nations. Consider, for example, Firdausi's Iranian verse epic, the ShahNameh, where the hero Rustum's journey is embodied in the seven quests. Similarly, Sundjata, the oral epic which narrates the origins of the ancient Mali empire, relates its eponymous hero's development through the perils of the journey he undertakes with his family. Written accounts of journeys also have a very long history. The earliest acknowledged travel narrative is the $14^{\text {th }}$ century BC text, The Journeying of the Master of the Captains of Egypt (Cuddon 937). An indication of the wealth of travel writing from different cultures at various periods in world history is suggested by two recent anthologies, Kumkum Chatterjee and and Clement Hawes' Europe Observed: Multiple Gazes in Early Modern Encounters and Tabish Khair's Other Routes: 1500 Years of African and Asian Travel Writing, mentioned above. These compilations bring together some of the travel writing and scholarship on travel writing across the ages from China, India, West Africa and Hawaii, as well as other parts of the world. 
From the anthropologist-ethnologist, Arnold von Gennep, we learn that frontier crossing often has a "magico-religious" aspect whereby one moves from the known of the community and its mores to the territory of the unknown, marked as evil. The boundary in terms of this magico-religious aspect can also be found closer to home.. Various cultures ascribe a sacred value to the threshold of the house. Thus the point of ingress or egress of the home also becomes a boundary. In this way the journey which necessarily entails border crossing is constitutive of the idea of community, since it demarcates the known from the unknown.

The journey is, however, even more intimately constitutive of community since it is an essential part of the self-realization of the persons who comprise the community. The concept of the journey is inescapably embodied in the rites of passage which mark full entry of the person into the community. Human self-realization is almost universally tracked as a voyage which involves border transitions allowing incorporation into a new developmental stage. Often these border transformations involve physically crossing a boundary. Initiation is a case in point in many cultures. The initiate crosses the boundary of the known, usually maternal, world, into the unknown, a liminal space where he is instructed in the lore of manhood. The boundary which marks his separation from the community is also that which marks his reincorporation. It is only in late modern conceptions of the self that liminality is often conceived as a permanent and desirable condition. Here the threshold zone where the rites of passage are undergone is permanently occupied. The transition from one status to another is relinquished for a subjectivity permanently destabilized by the uncertainties of the borderland. In terms of such conceptions of the self, where one is perpetually travelling in the borderland, the distinction between being at home and being away from home also collapses.

Travel, it is clear, constitutes the subject, but the process and the matrix of that formation have been subject to change. Border crossing is an inescapable dimension of the journey. The concept of the border and the changes it undergoes in historical time may be considered a symbolic nexus of the broader transformations of the subject and worldviews. This essay explores the constitutive relationship between ideas of the self, the motif of the journey and concepts of territory. The territory under examination is continental Africa. To compare and contrast fundamentally different views of Africa, the travelogues of a non-modern, a modern and a late-modern traveller will be juxtaposed and examined. The travel narratives of the $14^{\text {th }}$-century jurist Ibn Battuta, the 19th-century explorer, adventurer and translator Richard Burton, and the $21^{\text {st }}$-century writer Paul Theroux will be considered, all of whom have traversed vast tracts of the world, passing through many cultures and climes. Following the exhortation for the believer to seek knowledge in the Prophetic Traditions, there is a wealth of Arab-Islamic world travel writing. Ibn J ubayyr's $12^{\text {th }}$-century travelogue is one of the earliest examples. Khair's collection Other Routes includes the description of the experiences of the Iraqi Christian priest, Ilyas, in South America in the 17th century. Nabil Matar in Europe Through Arab Eyes considers a wide variety of sources of Maghrebian views and attitudes towards their northerly neighbours in the early modern period, including examples of travel writing. Matar reinforces the view 
generally held by scholars that "Arab" is not a racial but a cultural marker. However, Ibn Battuta's Rihla remains one of the few pre-modern accounts of extensive travel in Africa. Ibn J ubayyr, whom Ian Richard Netton dubs the "observant traveller", describes his experiences only in Egypt, in particular the medieval "tourist" destinations of Cairo, en route to pilgrimage in Mecca. By contrast, Ibn Battuta travels overland through most of North Africa, calls at the main ports on the East African coast, and journeys to parts of sub-Saharan Africa. Arabic sources for East Africa are legion and, undoubtedly, include travelogues (Mukhtar 141-72). Unfortunately, most of these sources are not available in English translation.

Translated sources of West African history for the medieval period are available and conveniently collected in the Corpus of Early Arabic Sources for West African History. Some of the most important manuscripts in the collection undoubtedly are the $11^{\text {th }}$-century text of Al Bakri, the $12^{\text {th }}$-century text of Al Idrisi, the 13 $13^{\text {th }}$-century text of Ibn Said and the 15th -century text of Ibn Khaldun. Al Bakri's work takes the form of a study of West Africa based upon other studies and the accounts of traders in the region. It is the principal source for the observations of the numerous other writers who follow him. Al Idrisi and Ibn Said's focus is geographical; Africa is absorbed into the framework of analysis which divides the world up into seven climes and seven regions. Along with brief allusions to the "hamitic" myth to explain phenotypical differences of sub-Saharan Africans in the very earliest sources, the works with a geographical slant propose the idea that "race" is not inherent, but dependent upon environmental conditions. Thus the white Berber, after seven generations in the clime of the Sudanese, will become black and vice versa. The Tunisian historian, Ibn Khaldun, regarded as the father of modern sociology, based his observations on North and West Africa on studies like Al Bakri's, but also on the "oral historical traditions from the Malian scholars he had met" (Levtzion and Hopkins 317). What these and the other early sources generally describe is an Africa regarded in much the same way as other parts of the world. For the Arab-Islamic narrator -- and often these narrators are ethnically Berber -- the social ideal against which others are judged is clear, and most often is based on an idea of virtue illuminated by revelation. In other words, the code by which one judges both oneself and others is based upon an understanding of transcendentally revealed ethics. Nakedness and cannibalism, for example, are disdainfully dismissed in terms of the belief in the law of God. However, regions which form part of the Bilad al Shirk, or Land of Polytheism, Paganism or Infidelity, upon accepting the narrators' worldview, are fully incorporated into the Bilad al Islam. Race in this context is entirely incidental. Roxann Wheeler observes a similar conception at play in early $18^{\text {th }}$-century British accounts of interactions with Africans. Wheeler suggests that:

Africans' colour [had] not yet emerged as the primary signifier of their identity or status. In fact, one of the most fascinating indications of the relative fluidity of categories of difference at this time occurs when a black man claims that he is white because he is a Christian. (22)

When journeying through Africa, the Arab-Islamic traveller evaluates his personal experience, as well as the settlements and people he encounters, through the same ethical filter applied in other regions of the world. A set of 
tropes associated specifically with Africa which implicitly suggests baleful African exceptionality appears not to have been applied. Richard E.Dunn, drawing on Marshall Hodgson, notes the "egalitarian contractualism" of this outlook, where there was a "relatively free play of relations among individuals who tended to size one another up mainly in terms of personal conformity to Islamic moral standards" (8). In terms of this worldview, blackness is not a deeply allusive trope suggesting psychic regression and primal origins of man. Similarly, disease and illness are briefly acknowledged and dismissed. They are associated with specific unhealthy locations and strangers are sometimes seen as more susceptible to them. The white man's grave does not in these accounts become the metaphor for Africa. There is reference to the harsh living conditions among a few peoples, a product of the harsh environment in which they find themselves. For the most part what are described are settled, fairly well-provisioned societies with internal orders of their own and protocols for the resolution of conflict. In this period "Africa" is not synonymous with perpetual poverty and anarchy. There are disruptions associated with empires which break out of their boundaries, the raid-andloot mode of production of nomadic pastoralists and non-modern forms of slavery both endogenous and exogenous. These, however, are the historical exceptions to societies which have an internal cohesion and which, for the most part, quietly coexist. Al Bakri's $11^{\text {th }}$-century study, for example, does not identify perpetual crisis and degeneration. Of course, given his background, he especially notes conversion to Islam among indigenous rulers and their subjects, but also the continued coexistence of pagan practices like the cult worship of a snake. His attention is directed to local produce and trade, and styles of dress and grooming, among other interests. He also foregrounds descriptions of landscape and fauna and flora (Levtzion and Hopkins 77-87). The Africa of continuous wars, a consequence of "tribalism", "clannism" and, most recently, "religious war" had not yet come into existence. Against this background of sources, Ibn Battuta's Rihla still stands out for the wealth of social and cultural detail it provides, since it is a personal account of travel, rather than a study based on the testimony of others.

Why travel in the $14^{\text {th }}$ century? For Ibn Battuta the primary motivation is simple. He travels to perform the pilgrimage obligatory on every Muslim once in a lifetime, health and wealth permitting. In fact, Ibn Battuta performs the pilgrimage six or seven times. In this respect, Ibn Battuta is not unlike the majority of medieval travellers, whether Muslim or not. Travel enforced by pilgrimage has for millennia been a fundamental paradigm for individual selfrealization within the sociality of a religious horizon. As a Maliki jurist who is also a sufi, Ibn Battuta in the course of his peregrinations visits the shrines of Muslim saints, or "the friends of God". Tim Mackintosh-Smith, one of Ibn Battuta's English translators, suggests that: "Would-be mystics had to keep on the move, not only to visit holy men but also to avoid spiritual stagnation. [ ... ] constant nomadism enabled the embryonic mystic to hatch out into a higher state of consciousness" (114). In addition, Ibn Battuta travels to fulfill his destiny. The destinations of his travels had been prophesied both by a holy man in Alexandria and in the writer's own dreams. Rather less profoundly, Ibn Battuta also travels for career advancement. He studies at the various Islamic centres of learning he passes through to improve his qualifications as a jurist. He also somewhat vaingloriously travels to be the most well-travelled 
man of his time and indeed for some time thereafter. Ross E. Dunn notes Ibn Battuta's competitive edge when meeting a seasoned Turkish traveller. Ibn Battuta triumphantly proclaims: "I have outdone him by visiting these regions" (Foreword xix). But he also appears to travel for the sheer enjoyment of it -- for almost 30 years, from Morocco in the west to China in the east, from the capital of Tatar Russia in the north to Kilwa in the south.

In the 19th century, Sir Richard Burton, in his narratives certainly, appears to lack the spiritual motivation, conventionally considered, which impels Ibn Battuta. Or perhaps one might say that, if Ibn Battuta is moved by God, Burton appears to be impelled by a Faustian pact with the Devil. Burton interrogates himself, questioning why he would give up the comforts of home for the risks and discomforts of travel. In a letter to Monckton Milnes, written from Dahomey, Burton suggests: "Starting in a hollowed log of wood - some thousand miles up a river, with an infinitesimal prospect of returning! I ask myself 'Why?' and the only echo is 'damned fool! ... the Devil drives'”' (qtd. in Brodie 15). Burton travels in part to write about travel, as the forewords to the narratives of his various expeditions expose quite openly. In the introduction to a publication of First Footsteps in East Africa, a title which reveals the sheer presumption of the man and his larger than life image of himself, Burton laments the fact that his travel writing has brought him scant profit, while his translation of the Arabian Nights, a work which he knows enjoys little prestige in Arabic letters, makes him a fortune in his old age. In the preface to his travels to the Lake regions, he perceptively notes that it would be impossible "to avoid egotism" in the travelogue, which is "a purely egotistical" narrative form (xiv). The travel narratives clearly are part of Burton's definition of himself, an index of a broader transformation where the subject is seen to form and develop himself purely out of his own internal resources in response to lived experience. If one considers the full range of Burton's work, a gradual transformation is apparent. Burton sensibly writes for the market. If he did not, he would not have the means to travel -- an activity for which, financial considerations aside, he, like Ibn Battuta, appears to have a passion. Knowing that he has an audience in the various London geographical and natural history societies, his writing increasingly becomes pseudo-scientific. Knowing that he enjoys a market among people with a taste for the exotic and a repressed Victorian penchant for the erotic, Burton often presents coded pornography as anthropological observation. But there are moments in Burton's narratives where the distant language of the poser breaks through into a lyricism intimating the exhilarating potential of travel in Burton's self-fulfillment. What is interesting about Burton the traveller is that he does not simply pass through the landscapes and the people he writes about. An acclaimed polyglot, he learns the languages of various people and adopts their sartorial styles. Assimilating the outlook of the local people, Burton crosses the boundary, moving from outsider to insider status.

In the $21^{\text {st }}$ century, Paul Theroux is a professional travel writer who, crudely expressed, must travel in order to produce manuscripts about travel. More significantly, however, Theroux appears to be a travel writer since mobility allows the adoption of a mode of identity which privileges routed (in the sense of travelling) rather than rooted (in the sense of located) identity, a conception which may be traced back to Flaubert, whom Theroux reads. The gaze of the 
flâneur in the travelogue, however, extends beyond the cityscape to the countryside. Flâneurie foregrounds a conception of the subject which values individuality and self-constructed horizons. In Dark Star Safari, the travel narrative under consideration, Theroux repeatedly models himself on a literary precursor, namely, Huckleberry Finn, Mark Twain's eponymous hero. Like Huck Finn, Theroux wishes to "light out for the territor[ies]". In the context of his African safari, this notion takes on a very geographically located implication. "Lighting out for the territories" in the African context, for Theroux, literally means heading for a dark space where one can drop out of the technologically-advanced, globally-connected world. He yearns to drop out of civilization into a place where he will be unobtainable and uncontactable: "Out of touch in Africa is where I wanted to be" (3). Theroux is pushed out of the technologically-advanced world for psychic recuperation in a space which he conceptualizes as a time-space of origins - the living tableau of contemporary Egypt, for example, is like the hieroglyphs from millennia past that he views in the museum. Like Twain's hero, Theroux desires to be a self-engendered man who is not the self-improving man of the rational Enlightenment. He wants to develop his individual, fluid mode of existence on the river of life apparently outside of a shared, mythically constituted horizon. This form of subjectivity, like the idea of travel in which they have their source, is about displacement, movement, shifting self-images and crossing boundaries.

A comparison of how these narratives are composed is also interesting. Ibn Battuta did not travel to write about his travel. He happened to narrate his tale in a garden a few years after his return when he was commissioned by the Sultan of Morocco to record the marvels he had seen. He then dictated his travels from memory, albeit the prodigious memory of a chirographic culture, to the more literary Ibn Juzayy. One may contrast this with Burton and Theroux, who keep notes on their travels for reworking into a manuscript on their return home. Theroux starts work on his manuscript a year after his return from Africa.

Whether the product of a manuscript or print capitalist culture, travel narratives are spurred on by the words and the songs of their travelling predecessors. Ibn Battuta, Mackenzie-Smith suggests, "was part of a long tradition of Maghribi travel writers" (29) and claims not to have entered the East until he had "committed to memory 34000 lines of pre-Islamic poetry" (28). Ibn Battuta travels in the footsteps of other travel writers from the Muslim world as Tim Mackintosh-Smith travels in Ibn Battuta's footsteps in the 21st century. Richard Burton reads Ibn Battuta in the Arabic and quotes him in his narrative. Paul Theroux appears to carry with him more books than clothes. The sacred text for Theroux appears to be J oseph Conrad's Heart of Darkness, which he claims to have read 13 times before the end of his trip. He also reads Mark Twain's Huckleberry Finn, as already mentioned, as well as The Innocents Abroad. Theroux is also familiar with the travel writing of Ibn Battuta, Burton, Livingstone and Stanley. What is interesting about Theroux is the way in which the deeper sources of his observations about Africa are derived more from fictions about travel than non-fiction travel narratives.

What observations may be made about the discourse used to represent travel in Africa in these travelogues from three different periods? In the course of his 
journeys, Ibn Battuta makes two visits to continental Africa. The first takes place relatively early in his career when he travels on the Red Sea, calling on various ports on the East African littoral. Ibn Battuta calls on the Sultan of "Maqdashaw" or Mogadiscio and the port of "Kulwa" or Kilwa, both of which appear to be prosperous, stable cities, in stark contradistinction to the Horn of Africa today. Ibn Battuta is well-received, impressed by the architecture and entirely familiar with the civilities he encounters. The motivation for the second trip, which takes place 23 years later, is a little unclear. Ibn Battuta travels from Morocco to Mali or "Bilad al Sudan", the land of black people. In contradistinction to black people, Ibn Battuta sees himself as white, as are the Berbers he meets en route. Interestingly, Ibn Battuta uses these descriptors entirely unselfconsciously with no idea of racial hierarchy attached. As L.P. Harvey suggests, Ibn Battuta "does not share the modern guilty preoccupation with negritude" (68). In some ways Ibn Battuta is highly critical of some of what he encounters in West Africa, but, by contrast, is even more scathing about his encounters in the Ukraine. In Bilad al Sudan, Ibn Battuta takes umbrage at what he takes to be lack of recognition of his worth. Clearly the Malian officials did not value Ibn Battuta as highly as he valued himself. Furthermore, he is not impressed in his travels through these regions by the syncretic Islam he encounters. He is outraged by some non-Islamic practices and views as comical certain other practices. But again, there is no 19thcentury racial element attached to his criticisms. He has far worse things to say about Shii Syrians on the question of religious observances.

As we have seen, Ibn Battuta is offended by some of the practices he comes across in Mali; likewise, some of the people among whom he travels appear to have contempt for his practices. What is interesting, however, is that the difference between the social codes of Ibn Battuta and the animist Malians he encounters does not present a threat to life and limb. Ibn Battuta does not at any stage appear to feel threatened. The relatively fixed matrices within which various people are constituted appear, outside of narrowly defined political motives, to allow for dealing with difference.

Ibn Battuta is also not tormented by questions of identity, since he lives in a time where the concept of "identity" has not yet appeared on the horizon. By descent a Berber and culturally Arab, Ibn Battuta is not existentially unsettled when resident among other cultures. Ibn Battuta is a Sunni Muslim of the Maliki maddhab. It is the unseen matrix or empowering mythology within which he is constituted, not an identity which must be performed. As a Maliki jurist in the Land of the Blacks, he is notably impressed by the:

Avoidance of injustice, for there is no people more averse to it, and their sultan does not allow anyone to practice it in any measure; the universal security in their country, for neither the traveller nor the resident there has to fear thieves or bandits; their punctiliousness in praying and compelling their children to do so. (289-90)

The world inhabited by Ibn Battuta and his companions is one where borders and "identities" yield or give, precisely because the person is oriented against a relatively clear social ideal which may not necessarily be the ideal of the other, but which is able to negotiate the other. The feeling that the other is something of an oddity is entirely mutual, created by the immersion in the cultural and religious code within which each is constituted and which each 
party takes to be the rational view of the world. Taking a step outside of oneself, and assuming one can view one's cultural make up from a universalist position outside of mythology, is not yet a possibility.

Most striking in the discourse which represents Ibn Battuta's sojourn is the complete absence of the tropes which come to represent contemporary "Africa", namely lack of will, poverty, regress into primitive origins and the graveyard of civilized man, which is not to suggest that Ibn Battuta's Bilad al Sudan is a tourist's paradise. Similarly, the obverse of this idea, namely, a mystically, spiritually united Africa also does not exist in Ibn Battuta's representation. Indeed, the contemporary concept of "Africa" does not exist.

What is striking about Richard Burton's numerous volumes on late 19thcentury African travel are the ways they are written with a popular scientific, prurient Victorian market in mind. Burton writes copy which must sell and which must bring him recognition among the various geographical, trade, and other societies, as well as in government circles. He reproduces, quite consciously, the 19th-century science of race, inscribing a hierarchy of civilization which moves from the most fair skinned at the apex and the darkest at the base. But what makes Burton's narrative different from the roughly contemporaneous works of Livingstone, Stanley and Speke is the fact that in Burton's discourse there is a contradictory pull between writing for the imperial capital and simply writing about the people of whom, in fundamental ways, he becomes a part. He is not, like the other explorers, a stranger moving through a strange land. He becomes the people he moves among. His text superficially gestures towards notions of Africa and civilizational regress, belied by his actual experiences. Burton generally travels with the assumption of his security and a complete confidence in the codes of honour of, for example, the nomadic pastoralists he finds himself among in East Africa, so much so that he ignores the warnings of Somali elders of a possible attack on the British stationed at Berbera. For Burton, Africa does not figure as the white man's grave. He suffers the rigours of illness when travelling and the hardships of climate and terrain as suffered by the locals.

Paul Theroux's Dark Star Safari derives its title from the 1999 theory of the existence of a "failed" brown dwarf star circling and absorbing the light of the sun. Theroux merges the discourse of astronomy with the tropes which come to represent Africa from around the mid 19th century, captured in the titles of H.M. Stanley's travelogues, Through the Dark Continent and In Darkest Africa. The overlap of these two discursive representations of Africa presents an almost incontrovertibly pessimistic view of Africa since the narrator presenting these views appears to occupy a mobile identity outside of a constitutive mythology. In other words, one cannot claim that Theroux is a bigot since, occupying a fluid identity, he appears to stand outside of any system of belief. The opening sentence of the travelogue morphs Pliny's observation "Ex Africa aliquid semper novi" into "All news out of Africa is bad". Like Conrad's Kurtz, Theroux heads for Africa precisely because he wants a retreat from the bright lights, the sun of civilization - he wishes to tumble "down the side of a dark star" (18). Africa thus comes to represent for Theroux "the anti-Europe, the anti-West, which it is sometimes defiantly, sometimes lazily. [ ... ] There was nothing of home here. Being in Africa was 
like being on a dark star" (124). Plumbing the depths of the metaphors, Africa is also "not home". In the German the "unhomely", the "unheimlich" is also the uncanny, the unknowable dark depths of the unconscious. Regress into the unconscious, the primitive, the origins of mankind is a trope which drives Theroux's narrative. The faces and features he sees in Egypt, for example, register as an introduction to "repeated themes" (19) which, as his journey progresses further into continental Africa, "went deeper, grew denser, got blacker" (19). Africa figures as the space of psychic and biological origins, but also of death. Africa in these narratives is linked with disease. It is confirmed as the white man's grave. Theroux contracts his illness homeward bound (after having had his bag stolen at a J ohannesburg hotel) -- "And so I arrived home Africanized - robbed and diseased" (495). The darkness of Africa, to a significant extent, for Theroux, is constituted by his impression that in Africa one is outside the loop of global communication networks -- in Africa he can avoid mobile phones and faxes. This, of course, is a curious observation to make in the context of the regions he passes through. It is often observed that nomadic pastoralists of the Horn have moved straight from an oral culture to a technological culture quite comfortable with audio internet features.

Curiously, Theroux, a cosmopolitan who distances himself from the selfimprovement, progress and civilization narratives of his forebears, produces a narrative about Africa which replicates those discourses in a way which cannot be challenged since it emanates from a subjectivity which presents itself as culturally mobile. The challenge to the concept of Africa as "Heart of Darkness" has been persuasively argued by Achebe, among others, and need not be repeated here. In an age of "borderless" territories and identities, Theroux produces a narrative about Africa which fixes all of Africa outside of civilization; and, even more curiously, this narrative enjoys popular currency. It is clear that in Ibn Battuta's 14th-century narrative, Bilad al Sudan may be The Land of the Blacks, but there is no symbolic blackness and mystical primitivism which associates the shape of Africa with the shape of the human heart, as was suggestively proposed by Graham Greene in Journey Without Maps.

On the question of border crossings, Mackintosh-Smith, who travels in the footsteps of Ibn Battuta, reminds us that "borders and passports in general are a modern discontent" (138). The territories through which Ibn Battuta journeys are not however borderless, as his description of the border controls at the town of Qatya, between Egypt and Syria, indicates. We discover later on that the town of Gaza, in an historical irony, has no wall, an observation elicited no doubt by the fact that most other towns do have walls. Yet crossing the boundaries represented by these walls is so insignificant as never to warrant any comment from the traveller. The only other reference to a border is in Southern Persia, where Ibn Battuta remarks that a madrasa marks the end of the territories of a particular king (67). In Africa, Ibn Battuta doubtless passes through tribal territories, marked in various ways, but they do not appear to represent a significant hurdle to free movement. Ibn Battuta also appears to be able to travel with minimal funds, relying on the largesse he receives on the road, confirming Ibn Jubayyr's observation about travel generally in that broad historical period, where "in every village people will 
shower you with your daily bread" (Mackintosh-Smith 30). Although, in Ibn Battuta's case, the traveller got a lot more than just his daily bread.

Ibn Battuta's experience of the cartographic reality of Africa is paradoxically confirmed, as late as 1935, by Graham Greene, who ventures through West Africa. The title of Greene's narrative, J ourney Without Maps, alludes to the fact that the territories he explores constitute a terra incognita since they have not been subjected to Enlightenment orders of rationality captured in colonial maps. Maps, of course, derive their possibility of existence from the existence of borders. The map "maps" the limits of territories, geographic and political. Harry Garuba notes the irony that, even though Greene purports to be passing through the unknown and unmapped, he repeatedly confirms arrival into new territory, known and mapped according to protocols familiar to others, but clearly unfamiliar to him. Borders exist on continental Africa prior to the formation of modern nation states. These boundaries, curiously, do not appear to represent much of an obstacle to mobility.

Burton's travels in East Africa in the late 19th century are punctuated by borders more significant than those encountered during the journey in Ibn Battuta's time. In one case, Burton refers to a road that is closed in the Somali territories because of inter-clan animosity due to the murder of a slave adopted as a son by one of the clan leaders. In another instance, a road is closed because of an outbreak of smallpox. Burton's travel is also not free. He has to pay tribute to various potentates. But what is interesting in Burton's case, unlike Mungo Park's experience a century earlier, is that Burton's tribute takes the form more of an exchange of gifts which formalizes a social relationship. The obligations associated with this social relationship are made clear when Burton falls ill and to effect his cure has a sheep sacrificed in his honour by the people he finds himself among.

Perhaps the most significant boundary Burton has to cross is the wall which encloses the legendary city of Harar, notoriously xenophobic especially to Christian travellers, the admission of whom, it was believed, would lead to the downfall of the city. Burton enters the city with his identity known. He is the anxious guest of its Amir for ten days (a few days longer than he would have liked). Afterwards, he rejoins his Bedouin travelling companions who had waited for him outside the city walls.

African borders loom very large and very threateningly in the narratives of contemporary travellers. For Theroux, descriptions of unpleasant experiences at borders occupy a substantial part of the narrative. Theroux refers to the extensive period he is forced to wait in Egypt while trying to get a Sudanese visa as his "Egyptian captivity" (19). He is obliged to fly from the Sudan to Ethiopia, despite his intention not to "parachute in" on cities, since the Sudanese-Ethiopian border is closed. If travel in Africa is the journey into the unknown, both literally and symbolically, then for Theroux, the African border is the absolute "terra incognita". The border is a distant place; "distant places were unknown; the unknown was dangerous" (125). The border, "what appears to be the edge, is the country's central reality" and that reality is the reality of backwardness and savagery. Every border crossed is represented in the narrative. He goes on to suggest: 
Border towns in African countries were awful places, known for riff-raff and refugees and people sleeping rough, famous for smugglers and back-handers, notorious for bribery and delay, nit-picking officialdom, squeezing policemen, pestering money-changers, the greatest risks, and the crummiest hotels. There was either a new national language on the other side of the border, or the same tribal language straddling it and a nasty border dispute because the dotted line ran through a divided people. Roadside customs and immigration were horrible bottlenecks, usually on the banks of a muddy river. (125)

Furthermore, contemporary travel in Africa is travel which must be entirely self-funded. Ibn Battuta, Mungo Park, Richard Burton and even Mary Kingsley, a Victorian woman travelling alone and unmolested in West Africa in the late 19th century, can enjoy the hospitality of the people they find themselves among even though they are complete strangers. In the Africa of the modern nation state and the uneven cultural, social and economic transformations associated with the modern nation state and its boundaries, the hospitality of the citizenry appears no longer to exist, since the social structures which guaranteed that hospitality have been systematically eroded. Theroux for the most part has to pay for accommodation; the age where any stranger enjoys hospitality within the bounds recognized by the particular culture he finds himself among appears to have passed.

The paradox in this transformation is clear. In an age of "fixed identities", boundaries seem to be more sinuous, open, permeable. But, more correctly, non-modern social formations do not recognize identity as a construct at all. In the contemporary period, where dominant global culture celebrates subjectivities that are fluid, mobile, transgressing boundaries of race, culture, creed, gender and sexuality, modern nation state border crossings, certainly in continental Africa, are very dark spaces indeed. The idea of Africa as the dark continent, which arises only in the late 18th century, has become a selffulfilling prophecy. Paul Theroux's 21st-century African travel narrative, which purports to represent a "cosmopolitan" view, where "cosmopolitanism" is understood to represent the democratic openness of a fluid identity, naturalizes the stereotype of Africa produced by the procedurally rational identity out of which "mobile" identity emerges. The transformation in the nature of the conception of the self is a complex index of social, cultural, political and economic transformations. Transformed ideas of self and community, self and its place in the cosmos, self and form of political organization, imposed on Africa through modern forms of colonialism have produced, with devastating effect, the "heart of darkness" the modern colonial imagination projected Africa to be. The current period, in which ideal identity is idealized as permeable and open, has the paradoxical effect of making sure that the borders, both literal and metaphorical, remain closed.

\section{Notes on contributor}

Dr F. Fiona Moolla is a Lecturer in the English Department at the University of the Western Cape. She is the author of the forthcoming monograph "Being At Home Everywhere": The Individual in the Novels of Nuruddin Farah, as well as of articles in The Journal of Commonwealth Literature and 
Comparative Literature Studies. Dr Moolla is also the author of short fiction and children's books on literary topics.

\section{Works cited}

Brodie, Fawn M. The Devil Drives: A Life of Sir Richard Burton. New York, London: Norton, 1967.

Burton, Richard F. A Mission to Gelele, King of Dahome. Vol 2. London: Tylston and Edwards, 1893.

---. First Footsteps in East Africa. Edited with an introduction and additional chapters by Gordon Waterfield. London: Routledge, 1966.

---. The Lake Regions of Central Africa: A Picture of Exploration. Introduction by Alan Moorehead. Vol. 1. New York: Horizon Press, 1961.

Chatterjee, Kumkum and Clement Hawes. Europe Observed: Multiple Gazes in Early Modern Encounters. Lewisburg: Bucknell UP, 2008.

Cuddon, J.A. The Penguin Dictionary of Literary Terms and Literary Theory. London: Penguin, 1998.

Dunn, Ross E. The Adventures of Ibn Battuta: A Muslim Traveler of the $14^{\text {th }}$ Century. Berkeley and London: U of California P, 1986.

---. "Foreword." Hamdun and King vii-xxxiii.

Garuba, Harry. "Mapping the Land/ Body/ Subject: Colonial and Postcolonial Geographies in African Narrative." Alternation 9. 1(2002): 87-116.

Greene, Graham. J ourney Without Maps. New York: Viking Press, 1936.

Harvey, L.P. Ibn Battuta. London, New York: I.B. Tauris, 2007.

Hamdun, Said and Noël King, trans. and eds. Ibn Battuta in Black Africa. With a 1994.

New Foreword by Ross E. Dunn. Princeton: Markus Wiener Publishers,

Hulme, Peter and Tim Youngs. The Cambridge Companion to Travel Writing. Cambridge: Cambridge UP, 2002.

Ibn Battuta. The Travels of Ibn Battutah. Abridged, introduced and annotated by Tim Mackintosh-Smith. Basingstoke and Oxford: Picador, 2002.

Ibn J ubayr. The Travels of Ibn Jubayr. Trans. R.J .C. Broadhurst. 1952. New Delhi: Goodword Books, 2001. 
Khair, Tabish et al. Other Routes: 1500 Years of African and Asian Travel Writing. Oxford: Signal Books, 2006.

Kingsley, Mary. Travels in West Africa. Abridged and introduced by Elspeth Huxley. London and Melbourne: Dent, 1987.

Levtzion, N. and J.F.P. Hopkins, eds. Corpus of Early Arabic Sources for West African History. Princeton: Markus Wiener Publishers, 2000.

Mackintosh-Smith, Tim. Travels with a Tangerine: From Morocco to Turkey in the Footsteps of Islam's Greatest Traveler. New York: Random House, 2004.

Matar, Nabil. Europe Through Arab Eyes 1578-172. New York: Columbia UP, 1999.

Mukhtar, Mohamed Haji. "Arabic Sources on Somalia." History in Africa 14 (1987): 141-72.

Netton, Ian Richard. Seek Knowledge: Thought and Travel in the House of Islam. Richmond: Curzon Press, 1996.

Park, Mungo. Travels into the Interior of Africa. 1799, 1815. Afterwords by Anthony Sattin. London: Eland, 2003.

Stanley. Henry Morton. In Darkest Africa or the Quest Rescue and Retreat of Emin Governor of Equatoria. Vol. 2. London: Sampson Low, Marston, Searle and Rivington, 1890.

---. Through the Dark Continent or The Sources of the Nile Around the Great Lakes of Equatorial Africa and Down the Livingstone River to the Atlantic Ocean. Vol. 2. London: Sampson Low, Marston, Searle and Rivington, 1878.

Theroux, Paul. Dark Star Safari: Overland from Cairo to Cape Town. 2002. London: Penguin, 2003.

Wheeler, Roxann. "Limited Visions of Africa: Geographies of Savagery and Civility in Early Eighteenth-Century Narratives." Writes of Passage: Reading Travel Writing. Ed. James Duncan and Derek Gregory. London: Routledge, 1999. 14-48. 